\title{
The joy of lottery play: evidence from a field experiment
}

\author{
Martijn J. Burger ${ }^{1} \cdot$ Martijn Hendriks $^{2}$ - Emma Pleeging ${ }^{2}$. Jan C. van Ours ${ }^{3,4,5}$
}

Received: 7 March 2019 / Revised: 6 February 2020 / Accepted: 17 February 2020 /

Published online: 27 February 2020

(c) The Author(s) 2020

\begin{abstract}
Buying lottery tickets is not a rational investment from a financial point of view. Yet, the majority of people participate at least once a year in a lottery. We conducted a field experiment to increase understanding of lottery participation. Using representative data for the Netherlands, we find that lottery participation increased the happiness of participants before the draw. Winning a small prize had no effect on happiness. Our results indicate that people may not only care about the outcomes of the lottery, but also enjoy the game. Accordingly, we conclude that lottery participation has a utility value in itself and part of the utility of a lottery ticket is consumed before the draw.
\end{abstract}

Keywords Lottery play $\cdot$ Happiness $\cdot$ Field experiment $\cdot$ Procedural utility

JEL Classification C93 · D12 · I31

Electronic supplementary material The online version of this article (https://doi.org/10.1007/s1068 3-020-09649-9) contains supplementary material, which is available to authorized users.

Jan C. van Ours

vanours@ese.eur.nl

Martijn J. Burger

mburger@ese.eur.nl

Martijn Hendriks

hendriks@ese.eur.nl

Emma Pleeging

pleeging@ese.eur.nl

1 Erasmus Happiness Economics Research Organisation and Erasmus School of Economics, Tinbergen Institute (Amsterdam/Rotterdam), Erasmus University Rotterdam, Rotterdam, The Netherlands

2 Erasmus Happiness Economics Research Organisation, Erasmus University Rotterdam, Rotterdam, The Netherlands

3 Erasmus School of Economics, Tinbergen Institute Rotterdam, Erasmus University Rotterdam, Rotterdam, The Netherlands

4 Department of Economics, University of Melbourne, Parkville, Australia

5 CEPR, London, UK 


\section{Introduction}

The average return on lottery tickets is typically just over $50 \%$, which is considerably lower than the average return on other gambling games, such as horse racing, blackjack and roulette (Clotfelter and Cook 1990). Although buying lottery tickets is not a rational investment from a financial point of view, lottery play is the most popular form of gambling and the majority of the population participates at least once a year in a lottery (Kearney 2005; Garvía 2007). In 2015, the sales in the European lottery sector amounted to approximately $€ 80$ billion (The European Lotteries 2015), with European citizens spending on average $€ 100$ per person per year on lottery tickets. To increase our understanding of lottery participation, we conducted a field experiment randomly providing free lottery tickets to some participants of an existing household panel survey.

In the economics literature, several explanations for widespread lottery play have been put forward. Already at the end of the 1940s, Friedman and Savage (1948) argued that lottery play offers an opportunity to win substantial amounts of money and improve one's socio-economic status at a relatively low stake. Following the Friedman-Savage hypothesis and its later extensions and modifications (e.g, Pryor 1976; Brunk 1981; Hartley and Farrell 2002; Nyman et al. 2008), lottery play is considered rational when it offers the opportunity to improve one's socioeconomic status or lifestyle when there are few or no other options to realize this otherwise. In prospect theory, widespread lottery play has been attributed to irrational beliefs that people uphold regarding their chances of winning a lottery since people tend to overweight the small chances of winning the lottery (Kahneman and Tversky 1979).

Although there is some empirical support for both the Friedman-Savage theory and prospect theory, several scholars (e.g., Conlisk 1993; Clotfelter and Cook 1990; Scott and Gulley 1995) argue that these theories only partly explain people's propensity to gamble. In particular, the Friedman-Savage theory suggests that lottery is predominantly played among the low and middle social classes. Poorer people indeed tend to spend a larger proportion of their income on lottery tickets (Beckert and Lutter 2013), but the theory cannot explain why people play the lottery also in those parts of the income distribution where additional wealth does not result in much additional expected utility (Walker 1998; Perez and Humphreys 2013). According to prospect theory, some people participate in lottery play because they largely overweight their small chances of winning. However, also this theory cannot explain widespread gambling because most lottery participants have quite rational expectations regarding the outcome of a draw (Forrest et al. 2000).

A different explanation for widespread lottery play that has received less empirical attention in the economics literature is that lottery play itself has a utility value (Hirshleifer 1966; Eadington 1973; Loewenstein 1987; Conlisk 1993; Le Menestrel 
2001). ${ }^{1}$ In other words, there is a non-monetary or process utility of participating in a lottery. Lottery players may experience positive emotions before and after the draw. Positive emotions before the draw may result from one's hope for a happier life, from the fun and excitement of the game as well as from social bonding activities when the lottery is played together with family or friends (Forrest et al. 2000; Guillén et al. 2011; Kocher et al. 2014). Positive emotions after the draw may originate from winning a prize, even when the prize is only very small and lower than the purchasing price of the lottery ticket. In addition to the monetary utility of winning a prize, there may also be a non-monetary utility of winning unrelated to the magnitude of the prize (Sheremeta 2010). Since most lotteries have many small prizes and the chance of winning a prize is high (in the lottery in our experiment the probability to win a prize is 50\%), this could explain the widespread popularity of lottery play, including (seemingly) irrational behavior and the fact that lottery play takes place across the whole income distribution.

While this utility of gambling model has considerable appeal, there is limited empirical evidence in support of this model (Perez and Humphreys 2013). This is probably due to the difficulty of identifying an appropriate observable proxy for the procedural utility generated by playing the lottery (see also, Nyman et al. (2008)). Happiness measures, as suitable indicators of procedural utility measures, have been suggested and applied in economic research (Frey and Stutzer 2002; Frey et al. 2004). Burger et al. (2016), using the British Gambling Prevalence Survey 2010, found a small positive effect of lottery participation on happiness for individuals who engage in lottery play for fun. Bruyneel et al. (2005) reported that the purchase of lottery tickets is associated with reducing negative mood. Along similar lines, in a lab experiment Kocher et al. (2014) identified hope and thrill as determinants of the popularity of Lotto tickets. Other studies showed a positive relationship between the hope of winning and lottery participation (Forrest et al. 2000; Clarke 2005; Ariyabuddhiphongs and Chanchalermporn 2007). These findings are also echoed in studies that examined the motives for lottery play: people do not only play for the money, but also for social bonding and fun (Miyazaki et al. 1999; Burger et al. 2016).

In our study, we focus on understanding participation in lotteries. We investigate the utility of lottery play using a field experiment. Some randomly selected participants in a regular panel survey were provided with a free ticket of the Dutch State Lottery while others were not. ${ }^{2}$ We assess the procedural utility of lottery play by comparing the change in momentary happiness (i.e. happiness experienced today)

\footnotetext{
1 Another explanation for the popularity of different gambling games is that lottery play is not perceived as gambling and relatively free of social stigma (Ariyabuddhiphongs 2011), unlike for example horseracing betting and casino play. In addition, lotteries are more accessible compared to other forms of gambling (Felsher et al. 2004) and characterized by an extreme skewness of prizes (there is often only one extreme big prize), which is thought to make lotteries relatively attractive (Garrett and Sobel 1999). However, a further discussion on the popularity of the lottery compared to other forms of gambling is beyond the scope of this paper.

2 The State Lottery is the largest draw game lottery in the Netherlands. In contrast to other games in the lottery industry (e.g. Lotto, Toto, or scratch cards), a draw game lottery is passive since players cannot choose exact numbers and there is often a long time between draws. Furthermore, the revenues from the lottery are confiscated by the government. So, in comparison with other lotteries which use revenues to support good causes, the state lottery does generate less "warm glow".
} 
of lottery players and non-lottery players at three points in time: (1) before receiving a (free) lottery ticket, (2) after receiving a lottery ticket but before the draw, and (3) after the draw. We examine both the procedural utility of lottery play before and after the draw. We hypothesize that before the draw, players may gain procedural utility from the excitement of playing the game, the hope of winning a large prize, as well as social bonding, while after the draw players may gain procedural utility from winning a small prize (which was in almost all cases smaller than the original retail price of the ticket). To rule out the possibility that the utility effect we observe is related to receiving a free lottery ticket, and to account for the fact that some people purchased a lottery ticket themselves, we compare four groups of people: with a free lottery ticket, with a purchased lottery ticket, with both a free and purchased lottery ticket, and without a lottery ticket.

Our paper contributes to the economics literature on lottery play and consumption in several ways. First, although many economic studies have addressed the utility gains of lottery wins, this is to the best of our knowledge the first paper to causally identify the procedural utility of lottery play using a large-scale field experiment. Second, in our study we take into account that lottery players may gain procedural utility before and after the draw. We find that lottery participation increases momentary happiness before the draw, but winning a small prize has no effect on momentary happiness. These results indicate that there is a procedural utility of gambling in the sense that people do not only care about winning prizes, but also enjoy the game. We conclude that lottery play has a utility value in itself. Third, and more generally, our article shows that consumption outcomes are not the only source of utility, but consumers also enjoy procedural utility, which is in turn a driving force behind consumer behavior (Frey and Stutzer 2002; Frey et al. 2004).

\section{Experimental design and data}

For our field experiment we used the CentERpanel, a household panel that is maintained by CentERdata, a research institute affiliated with Tilburg University. The panel is representative of the Dutch population and exists since 1991. Currently, the CentERpanel contains well over 2000 households. Panel members use their computers or smartphones to participate in the study and complete questionnaires on a weekly basis. All CentER panel survey participants get compensated for filling out surveys by receiving CentERpanel points, which can be exchanged for money or a gift certificate, or can be donated to charity. The number of points people received for filling out our survey was the same for people who received a free lottery ticket and people who did not receive a free lottery ticket. ${ }^{3}$

The initial objective of our field experiment was twofold: (1) investigate how people that infrequently play the lottery experience lottery play and (2) investigate the

\footnotetext{
3 On average, CentERpanel participants receive 25 points per questionnaire, which has the value of 1 euro. Panelists who participate longer receive extra points. Specifically, after 40 weeks of participation a households receives 1.5 times the regular number of points, and after 100 weeks of participation households receive twice the regular number (Teppa and Vis 2012).
} 
non-monetary utility effects of lottery play. ${ }^{4}$ Participants in our experiment filled out a questionnaire at three moments in time. The first questionnaire, held between April 17-28, $2015\left(T_{1}\right)$ and filled out by 1611 panel members, was intended to obtain information about the participants' baseline level of subjective well-being, their gambling behavior-particularly with regard to lottery games-and their sociodemographic characteristics and personality. Subsequently, a large 1300 respondents $(81 \%)$ were randomly invited to participate in the field experiment. Of the 1300 invitees, $1100(85 \%)$ randomly received a free "full" lottery ticket (purchase price: $€ 15)$ to participate in the State Lottery. Please note that the main reason why many people received a free ticket is that one of the objectives of the study was to investigate how people that infrequently play the lottery experience lottery play. ${ }^{5}$ This ticket was sent approximately one week before the State Lottery draw of May 10, $2015 .^{6}$

Next, all participants were asked to fill out a second questionnaire between May 8-10, $2015\left(T_{2}\right)$ with questions about their subjective well-being and thoughts about lottery play. After the draw of May 10, respondents were asked to complete a third questionnaire between May 10-12, $2015\left(T_{3}\right)$ about their subjective well-being, the outcome of the lottery draw (whether the participant won a prize or not), and thoughts about lottery play. ${ }^{7}$ In total, 1299 participants finished the questionnaires at $\left(T_{1}\right)$ and $\left(T_{2}\right)$, while 1155 participants filled out all three questionnaires. After deleting observations with missing data, the analysis sample includes 1142 participants in the $T_{1}-T_{2}$ comparison and 1097 respondents in the T1-T3 comparison. We base our analyses on these two groups. To examine the effect of lottery play on procedural utility, we distinguish four groups: (1) people without a ticket, (2) people with only a free lottery ticket, (3) people with only a purchased lottery ticket, and (4) people with both a free and purchased lottery ticket. ${ }^{8}$ This distinction is important for

\footnotetext{
${ }^{4}$ For this reason, we gave many people a free lottery ticket, resulting in the uneven group sizes for the four experimental conditions.

5 Individuals can participate in the State Lottery in the Netherlands by buying separate lottery tickets or through a subscription. About half of the individuals who bet in the State Lottery do so through a subscription. There are monthly draws of winning tickets and sometimes special draws are organized at the end of the year or on other occasions. There is also a Jackpot, an additional large prize of at least $€ 7.5$ million. The Jackpot is not guaranteed in each draw and, if there is no ticket that wins the Jackpot in a certain draw, the full amount is transferred to the next one. For participants, there is choice between "full" tickets of $€ 15$ and "partial" tickets of $€ 3$ which pays one fifth of the full amount if it is a winning ticket. Bigger prizes in each draw range from $€ 1000$ to $€ 1$ million. Each draw also has smaller prizes, ranging from $€ 5$ to $€ 1000$. In our experiment, at most one person per household could participate in the experiment. Total ticket spending on the project amounted to $€ 16,500$. It was fully clear to respondents that the free State Lottery ticket they received was related to their participation in the CentERpanel. Two respondents in our experiment returned the lottery ticket for religious reasons.

${ }^{6}$ In May 2015 the Jackpot of $€ 13.5$ million was paid out; the expected earnings were $€ 10.25$ per ticket. In 2015 there were 16 draws of the State Lottery with a total revenue of $€ 692$ million and a net of lottery taxes prize money of $€ 413$ million which makes an average of $€ 26$ million of prize money per draw (see Nederlandse Staatsloterij 2016).

7 The possibility to fill out the questionnaire at $T_{2}$ ended before the draw on May 10 . The possibility to fill out the questionnaire at $T_{3}$ started after the draw on May 10.

${ }^{8}$ As suggested by one of the reviewers, an alternative setup would be to incorporate a condition in which one of the groups receives cash. However, due to budget limitations we were not able to extend the experiment.
} 
two reasons. First, in our field experiment we cannot rule out that people purchase or have already purchased tickets for the lottery draw. By giving away free tickets for the lottery draw, we try to bypass the problem that our results could be distorted by a selection of happy people or thrill-seekers into lottery play. Second, having only participants with a free ticket and no purchased tickets would also have been a problem, since the procedural utility of participants can originate from obtaining the free ticket itself, when this is considered as a small gift. Overall, we have in our field experiment 122 participants with no ticket, 673 participants with only a free ticket, 49 participants with only a purchased ticket, and 298 participants with both a free and purchased ticket.

We capture procedural utility with momentary happiness, which is measured by the following question: 'How happy do you feel today?' with answer categories ranging from 1 (very unhappy) to 10 (very happy). ${ }^{9}$ In particular, we are interested in how people's daily happiness develops around the lottery draw. On average, the participants in the field experiment scored 7.6 in the first questionnaire, 7.5 in the second questionnaire, and 7.4 in the third questionnaire. These scores are comparable to the average happiness obtained in the Netherlands from other Dutch surveys (Veenhoven 2018). ${ }^{10}$

Because of the experimental set-up there is no need for including control variables but we nevertheless did this to account for possible non-randomness in the set-up. As control variables, we included several personal and personality characteristics. The personal characteristics we included are gender, age, income, educational attainment, occupational status, marital status, household composition, and characteristics of the place of residence. The personality characteristics we included are based on answers to questions regarding level of materialism, locus of control, and degree of optimism. In addition, we controlled for the general gambling behavior of the respondents as well as the date on which the respondents completed their questionnaires and how they experienced the survey questionnaires, i.e. whether they enjoyed answering the questions or whether they found it difficult. Finally, we controlled for changes in life satisfaction in the period under observation to account for possible events that affected people's happiness with life over the period studied. Nevertheless, it should be noted that the evaluation of life satisfaction is-like happiness today-also dependent on momentary moods. Hence, the models in which

\footnotetext{
9 We use a more momentary measure of subjective well-being instead of the more stable life satisfaction measure, since procedural utility is better operationalized by survey questions that capture 'happiness in life' than survey questions that capture 'happiness with life' (Veenhoven 2000).

10 Declining happiness scores have also been found in other panel studies where through panel conditioning people report lower happiness scores the longer they participate in a panel (Chadi 2013) whereas Van Landeghem (2014) notes that these panel effects vary widely across studies. However, because of the small calendar time period between our subsequent surveys panel attrition is an unlikely candidate to explain the overall drop in happiness we find. Nevertheless, even over a short time period circumstances under which respondents fill in questionnaires may differ. We find that reported happiness is higher in weekend-days and lower on rainy days. This explains at least part of the drop in overall happiness. The gap between T1 and T2 is largely explained by more rain in T2 while a substantial part of the drop in happiness between $\mathrm{T} 1$ and $\mathrm{T} 3$ is explained by almost half of the respondents answering the T1 questionnaire in the weekend compared to no-one in $\mathrm{T} 3$.
} 
we control for life satisfaction changes can be considered as conservative estimates for the procedural utility of lottery play. ${ }^{11}$

As a robustness check, we investigated whether the joy of lottery play was contingent on thoughts about the lottery draw and positive and negative feelings regarding the draw, and willingness to pay for a lottery ticket. In our survey at $T_{2}$, we asked the respondents how often they thought about the State Lottery. Answer categories ranged from 1 (never) to 7 (all the time). In addition, lottery players were asked the following question before the draw $\left(T_{2}\right)$ : 'What emotions do you experience when you think about your participation in the draw of the State Lottery of May 10th?'. ${ }^{12}$ Respondents indicated on a scale from 1 (not at all) to 7 (completely) to what extent they felt happy, hopeful, excited, curious, trusting, amused, and friendly (positive emotions) as well as to what extent they felt worried, sad, annoyed, disappointed, regret, distant, and indifferent (negative emotions). Willingness to pay was examined in the survey at $T_{1}$, where participants had to make a choice between receiving a small sum of money or a lottery ticket with a retail price of $€ 15$ in a hypothetical experiment. An overview of the variables included in the analysis is presented in Appendix A, while the questionnaires are available in online Appendix B.

\section{Procedural utility before the draw}

We start our analysis by investigating the presence of procedural utility before the draw. Through linear regression, we related happiness to the type of lottery ticket people possessed (purchased, free or both) and to a series of control variables. To remove observed and unobserved time-invariant characteristics from the analysis, we used as dependent variable the change in happiness between survey 1 and survey 2, $\Delta H_{12, i}$. We assume the following relationship:

$$
\Delta H_{12, i}=\alpha_{1}+\beta_{1} F_{i}+\beta_{2} B_{i}+\beta_{3} C_{i}+\beta_{4} X_{i}+\beta_{5} \Delta S_{12, i}+\beta_{6} \Delta L S_{i}+\varepsilon_{12, i}
$$

where $\alpha_{1}$ represents a vector of interview date fixed effects, $i$ refers to an individual, $F$ is a dummy variable for whether or not a free lottery ticket was received (but no lottery ticket was bought), $B$ is a dummy variable with value 1 if no free lottery ticket was received but one was bought, $C$ is a dummy variable with value 1 if the individual had received a free lottery ticket in addition to having bought one, and $\Delta$ indicates the first difference of a variable. Furthermore, $X$ is a vector of personal and personality characteristics, $S$ if a vector of survey characteristics and $L S$ represents life satisfaction. Finally, $\beta_{1}$ to $\beta_{6}$ are our (vectors of) parameters and $\varepsilon_{12}$ is an error term.

\footnotetext{
11 Although controlling for life satisfaction takes into account changes in one's life that cannot be attributed to obtaining a lottery ticket between $T_{1}$ and $T_{2}$, this variable is endogenous because of the halo effect: people in a better mood, evaluate all aspects of life and life in general higher.

${ }^{12}$ A similar question was asked in $T_{3}$ where participants also had to reflect on their emotions regarding the draw of May 10.
} 
Table 1 Parameter estimates change in happiness between $T_{1}$ and $T_{2}$

\begin{tabular}{lllll}
\hline Panel A & & & \\
$\quad$ Lottery ticket $\left(\beta_{1}=\beta_{2}=\beta_{3}=\beta_{1}^{*}\right)$ & $0.40(0.12)^{* *}$ & $0.37(0.13)^{* *}$ & $0.25(0.11)^{*}$ & \\
$R^{2}$ & 0.01 & 0.07 & 0.20 & \\
Panel B & & & & \\
$\quad$ Free ticket $\left(\beta_{1}\right)$ & $0.38(0.13)^{* *}$ & $0.37(0.13)^{* *}$ & $0.26(0.12)^{*}$ & \\
$\quad$ Free ticket—no lottery play last year $\left(\beta_{1 a}\right)$ & & & $0.27(0.12)^{*}$ \\
$\quad$ Free ticket—-state lottery play last year & & & & $0.26(0.14) \#$ \\
$\quad\left(\beta_{1 b}\right)$ & & & & \\
Purchased ticket $\left(\beta_{2}\right)$ & $0.56(0.20)^{* *}$ & $0.52(0.21)^{*}$ & $0.39(0.21) \#$ \\
Free and purchased ticket $\left(\beta_{3}\right)$ & $0.40(0.13)^{* *}$ & $0.34(0.14)^{*}$ & $0.19(0.13)$ \\
$R^{2}$ & 0.01 & 0.07 & 0.20 & 0.20 \\
$\beta_{1}=\beta_{2}(p$ value $)$ & 0.31 & 0.38 & 0.51 & \\
$\beta_{1}=\beta_{3}(p$ value $)$ & 0.86 & 0.74 & 0.30 & \\
$\beta_{2}=\beta_{3}(p$ value $)$ & 0.36 & 0.31 & 0.29 & \\
$\beta_{1 a}=\beta_{1 b}(p$ value $)$ & & & & 0.96 \\
Personal controls & No & Yes & Yes & Yes \\
Lottery behavior controls & No & Yes & Yes & Yes \\
Survey controls & No & Yes & Yes & Yes \\
Change life satisfaction & No & No & Yes & Yes \\
\hline
\end{tabular}

Based on 1142 observations; reference group: no ticket; robust standard errors in parentheses $* * p<0.01, * p<0.05, \# p<0.10$

In case of procedural utility before the draw, we expect that the change in happiness between $T_{1}$ and $T_{2}$ is significantly larger for lottery participants than for nonlottery participants. Furthermore, we expect that the change in happiness between $T_{1}$ and $T_{2}$ is not significantly larger for lottery participants with a free ticket than for lottery participants with a purchased ticket. If there would be a difference, the increase in happiness could be related to a monetary transfer, i.e. receiving the lottery ticket for free.

Table 1 provides the OLS parameter estimates for the change in happiness between $T_{1}$ and $T_{2}{ }^{13}$ The first column shows the parameter estimates of the lottery ticket effect on the change in happiness without including control variables. On average, people with a lottery ticket report a significantly higher change in happiness score (Panel A), where there are no significant differences between players with only a free ticket, a free and purchased ticket, and only a purchased ticket (Panel B). ${ }^{14}$ As

\footnotetext{
13 The full estimation results can be found in online Appendix C. The estimation results show the effects of gradually introducing groups of control variables.

14 We can only speculate about the reasons why the three groups experience similar happiness effects. On the one hand, a larger effect could be expected for people with a purchased ticket because people who derive relatively more utility from lottery play are more likely to have already purchased a lottery ticket (a self-selection mechanism). On the other hand, we cannot rule out that there is a small gift effect for people with a free ticket. A likely reason that people with both a purchased and free ticket were not hap-
} 
shown in the second column, our results are robust to including several groups of control variables, i.e. personal characteristics, lottery behavior variables and survey characteristics. In the third column, we also control for the change in life satisfaction in the period between $T_{1}$ and $T_{2}$ - which can be considered a very conservative estimate of the lottery play effect. Even then, the effect of obtaining a lottery ticket on the change in happiness is positive and significant. All in all, we conclude that on a scale from 1 to 10 , participating in a lottery increases happiness with $0.25-0.40 .{ }^{15}$

One potential problem in our analysis is that in the group of free ticket holders there are individuals that intended to buy a ticket but a free one came along and the purchase never happened. In a sensitivity analysis represented in the fourth column of Table 1, we therefore distinguish between holders of free tickets who played the State lottery last year (and therefore have a higher chance to have the intention to buy a ticket) and holders of free tickets that did not play the State lottery in the last year. As shown, there is no difference in happiness gain between $\mathrm{T} 1$ and $\mathrm{T} 2$ between the two groups. In the group of people who participated in the State lottery last year, we made a further distinction between frequent and infrequent gamblers (at least monthly vs. less than one time per month). Again, we find no difference between the different groups. ${ }^{16}$

It can be argued that it is difficult to gain procedural utility from a lottery draw if one never thinks about the lottery. Hence, we re-estimated our models, using information from the survey shortly before the lottery draw. More specifically, we investigated whether the intensity of thinking about the lottery affects the change in happiness before the lottery draw, i.e. between $T_{1}$ and $T_{2}$. Here, we distinguish between three groups of lottery players: players that never thought about the lottery (answer category $1 ; 15 \%$ of the lottery players), players that sometimes thought about the lottery (answer category 2-3; 69\% of the lottery players), and players that frequently thought about the lottery (answer category 4 or higher; 16\% ) using the following equation:

\section{Footnote 14 (continued)}

pier than people with either a purchased or free ticket is because of strong decreasing returns of an extra ticket. With one ticket you can dream as much about winning the lottery as with multiple tickets.

15 Statistically, we observe that between T1 and T2 the momentary happiness in the group of participants decreases less than in the group of non-participants. As noted by one of the reviewers, an alternative explanation for our findings could be that the happiness of the non-participants was negatively affected because of answering questions about a lottery in which they did not participate. However, it is very unlikely that this causes the drop in momentary happiness of non-participants because the question about momentary happiness was not directly related to lottery play and it was asked at the beginning of the survey. In addition, the participants without a ticket were not informed that other CentER panel participants had received lottery tickets, and they did not receive any further questions about lottery participation.

16 We also investigate heterogeneity in the effect of having a lottery ticket on the change in happiness between T1 and T2. We did not find heterogeneous effects across educational attainment, income level, socioeconomic status, gender, age, having children, geographic area of residence and materialistic disposition. We find heterogeneity in the effect of having a lottery ticket on happiness change between T1 and T2 across marital status (for singles the effect is stronger), original happiness level (people that score high have less to gain), and locus of control (for people with external locus of control the effect is stronger). 


$$
\Delta H_{12, i}=\alpha_{2}+\gamma_{1} L T_{i} I_{1, i}+\gamma_{2} L T_{i} I_{2, i}+\gamma_{3} L T_{i} I_{3, i}+\gamma_{4} X_{i}+\gamma_{5} \Delta S_{12, i}+\gamma_{6} \Delta L S_{i}+\epsilon_{12, i}
$$

where $\alpha_{2}$ represents a vector of interview date fixed effects, $L T$ is a dummy variable indicating whether or not an individual had a lottery ticket irrespective of whether this was bought or received because of the field experiment and $I_{1}-I_{3}$ are dummy variables indicating whether the individual had no thoughts about the lottery, sometimes thought about the lottery or frequently thought about the lottery. And, $\gamma_{1}-\gamma_{6}$ are (vectors of) parameters.

The first column of Table 2 shows that players who never thought about the lottery did not experience a significantly higher increase in happiness than non-players. At the same time, players who thought about the lottery experienced higher increases in happiness than non-players and players who never thought about the lottery. As shown in the second and third columns, the difference remains significant if we include control variables and also the change in life satisfaction. The fourth to sixth column of Table 2 show that our results hold if we account for the intensity of thinking about the lottery draw. The change in happiness between $T_{1}$ and $T_{2}$ after receiving a lottery ticket is present if the individual thought about the lottery, but it does not matter whether the individual thought about the lottery sometimes or frequently.

Along similar lines, it is difficult to gain procedural utility from a lottery draw if one does not have positive feelings when thinking about the lottery. Accordingly, we examined to what extent the procedural utility from a lottery draw is contingent on having overall positive emotions when thinking about the draw. In this regard, it is also interesting to note that participants thinking regularly about the draw experience higher levels of positive emotions and not higher levels of negative emotions compared to participants thinking never or only sometimes about the draw (see Fig. 1). We observe this across the whole range of positive emotions. ${ }^{17}$ In our regression, we investigate whether having positive emotions about the draw affects the change in happiness before the draw (again between $T_{1}$ and $T_{2}$ ), where we take the balance of positive to negative affect (PANA) score regarding the draw as main indicator for the positivity ratio when thinking about the draw. We use the following equation:

$$
\Delta H_{12, i}=\alpha_{3}+\phi_{1} L T_{i}+\phi_{2} L T_{i} P N_{2, i}+\phi_{3} X_{i}+\phi_{4} \Delta S_{12, i}+\phi_{5} \Delta L S_{i}+v_{12, i}
$$

\footnotetext{
17 Of course, some respondents may be biased toward more positive answers regarding the State Lottery because they have received a free ticket through their participation in the panel. Although these reciprocal feelings may influence the PANA score, it should not influence the relationship between the PANA score and momentary happiness because our happiness measure has no direct relation with the receipt of a free lottery ticket (a "gift"). The balance of positive to negative emotions is also known as the positivity ratio and estimated as the average positive affect (PA) score minus the negative affect (NA) score. An overview of the emotions included can be found in Fig. 1 and the methodology section. A potential problem with the PANA measure is that some emotions regarding the draw may have been affected by the reception of a free ticket. Hence, we re-estimated our model including only future-oriented positive emotions that are only affected by the upcoming draw (hopeful and curious) and excluding those positive emotions that are potentially affected by the receipt of a free gift (happy, friendly, trusting, amused, and excited). These results are available upon request and yielded no different conclusions.
} 
Table 2 Additional parameter estimates change in happiness between $T_{1}$ and $T_{2}$ : thinking about the draw

\begin{tabular}{|c|c|c|c|c|c|c|}
\hline \multicolumn{7}{|c|}{ Lottery ticket and thoughts about lottery } \\
\hline No thoughts $\left(\gamma_{1}\right)$ & $0.08(0.17)$ & $0.16(0.16)$ & $0.07(0.14)$ & $0.08(0.17)$ & $0.16(0.16)$ & $0.07(0.14)$ \\
\hline $\begin{array}{l}\text { Thoughts } \\
\qquad\left(\gamma_{2}=\gamma_{3}=\gamma_{2}^{*}\right)\end{array}$ & $\begin{array}{l}0.45 \\
\quad(0.13)^{* *}\end{array}$ & $\begin{array}{l}0.41 \\
\quad(0.13)^{* *}\end{array}$ & $0.29(0.12)^{*}$ & & & \\
\hline $\begin{array}{l}\text { Thought some- } \\
\text { times }\left(\gamma_{2}\right)\end{array}$ & & & & $0.41(0.13)^{* *}$ & $0.39(0.13)^{* *}$ & $0.27(0.12)^{*}$ \\
\hline $\begin{array}{l}\text { Thought frequently } \\
\left(\gamma_{3}\right)\end{array}$ & & & & $0.62(0.15)^{* *}$ & $0.52(0.16)^{* *}$ & $0.39(0.14)^{* *}$ \\
\hline$R^{2}$ & 0.02 & 0.08 & 0.20 & 0.02 & 0.08 & 0.20 \\
\hline$\gamma_{1}=\gamma_{2}^{*}(p$ value $)$ & 0.00 & 0.04 & 0.04 & & & \\
\hline$\gamma_{1}=\gamma_{2}(p$ value $)$ & & & & 0.01 & 0.07 & 0.06 \\
\hline$\gamma_{1}=\gamma_{3}(p$ value $)$ & & & & 0.00 & 0.02 & 0.02 \\
\hline$\gamma_{2}=\gamma_{3}(p$ value $)$ & & & & 0.06 & 0.21 & 0.23 \\
\hline Personal controls & No & Yes & Yes & No & Yes & Yes \\
\hline $\begin{array}{l}\text { Lottery behavior } \\
\text { controls }\end{array}$ & No & Yes & Yes & No & Yes & Yes \\
\hline Survey controls & No & Yes & Yes & No & Yes & Yes \\
\hline Change life satisfaction & No & No & Yes & No & No & Yes \\
\hline
\end{tabular}

Based on 1140 observations; reference group: no ticket; robust standard errors in parentheses

$* * p<0.01, * p<0.05, \# p<0.10$

where $\alpha_{3}$ represents again a vector of interview date fixed effects and $L T$ is a dummy variable indicating whether or not an individual had a lottery ticket irrespective of whether this was bought or received because of the field experiment, $P N$ is a meancentered continuous variable indicating a respondents' positivity ratio (PANA) regarding the draw. And, $\phi_{1}$ to $\phi_{5}$ are (vectors of) parameters. Our regression results are presented in Table 3. The first two columns show that players who had a higher positivity ratio regarding the draw experienced higher increases in happiness, where column 3-6 show that these results are primarily driven by the positive emotions. To exemplify, players that had no or hardly any positive emotions at all regarding the draw (maximum average score on the PA of 2 out of 7), did not experience an increase in happiness between $T_{1}$ and $T_{2}(p=0.086)$.

Indirectly, the joy of lottery play could also be inferred from people's willingness to pay for a lottery ticket. In the survey at $T_{1}$, participants indicated their willingness to pay for a lottery ticket. In a hypothetical experiment, participants made a choice between receiving a small sum of money or a lottery ticket with a retail price of $€ 15$. Although this can also indicate that people overestimate the expected value of a lottery ticket, many people choose to get the lottery ticket when the amount of money they would have received was larger than the retail price of the lottery ticket. Most notably, $43 \%$ of the participants preferred the lottery ticket over receiving $€ 17.50$, while even $30 \%$ of the participants preferred the lottery ticket over receiving $€ 25 .^{18}$

\footnotetext{
18 This suggests that for these participants, the transaction costs of buying a lottery ticket were perceived to be more than $€ 10$, i.e. the difference between $€ 25$ and the price of a lottery ticket. At the same time, participants realized that the chances of winning were small. Our survey showed that well over $80 \%$ of
} 


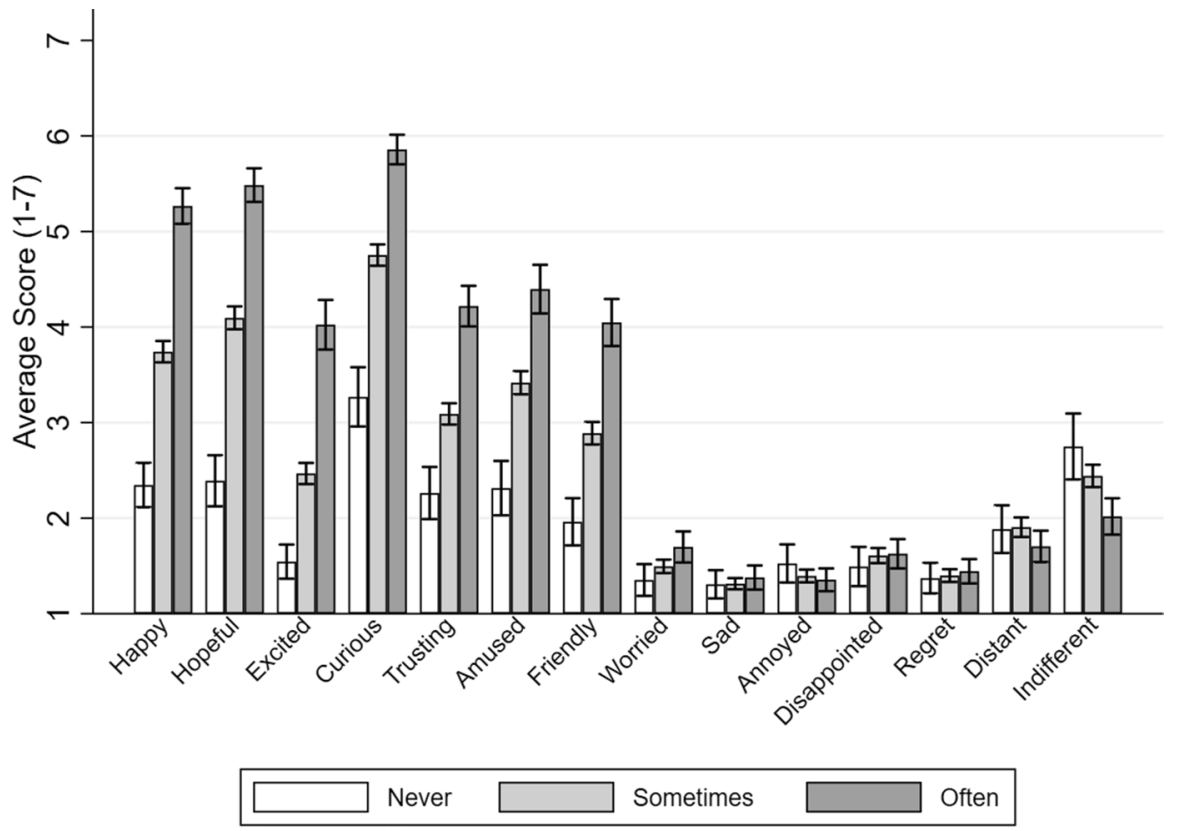

Fig. 1 Positive and negative emotions about participation in the State Lottery; experienced before the lottery draw by frequency of thinking about the draw Note: Only for respondents who possessed a lottery ticket for the lottery draw of May 10; average answers to questions on emotions on a scale from 1 (not at all) to 7 (completely)

\section{Procedural utility of winning a small prize}

We want to assess the happiness effect of winning a small lottery prize. For this, we related the change in happiness between surveys 1 and $3, \Delta H_{13, i}$ to explanatory variables as follows:

$$
\begin{aligned}
\Delta H_{13, i} & =\alpha_{4}+\left(\delta_{1} F_{i}+\delta_{2} B_{i}+\delta_{3} C_{i}\right)\left(1-P_{i}\right) \\
& +\left(\delta_{4} F_{i}+\delta_{5} B_{i}+\delta_{6} C_{i}\right) P_{i}+\delta_{7} X_{i}+\delta_{8} \Delta S_{12, i}+\delta_{9} \Delta L S_{i}+\varepsilon_{13, i}
\end{aligned}
$$

where $\alpha_{4}$ represents a vector of interview date fixed effects, $P_{i}$ is a dummy variable for whether or not the individual won a (small) prize and $\delta_{1}$ to $\delta_{9}$ are (vectors of) parameters.

In case of procedural utility after the draw, originating from winning a small prize, we expect that the change in happiness between $T_{1}$ and $T_{3}$ is significantly larger for lottery winners than for non-players. Furthermore, we expect that the change in happiness between $T_{1}$ and $T_{3}$ is significantly larger for lottery winners than

Footnote 18 (continued)

the respondents that regularly played the lottery thought that the chance to win a large prize in the lottery is small to very small, while less than $5 \%$ thought that the chance was large to very large. 


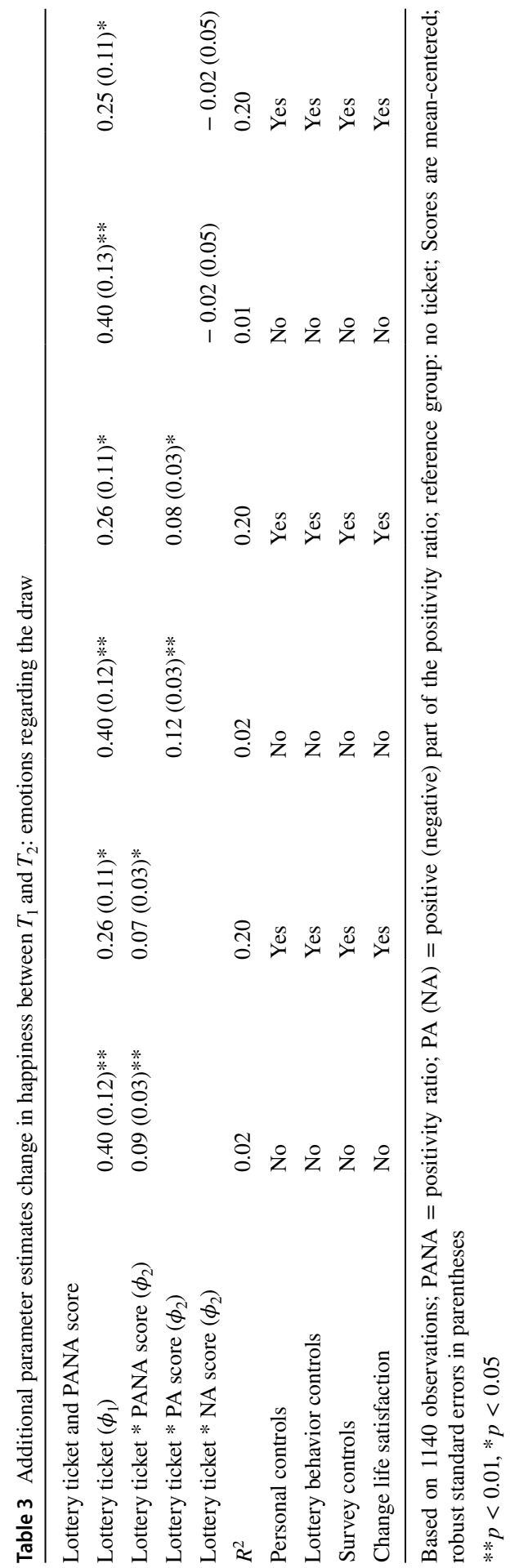


for non-lottery winners. Finally, we expect that the change in happiness between $T_{1}$ and $T_{3}$ is not significantly larger for lottery winners with a free ticket than for lottery winners with a purchased ticket.

In the draw in which the participants of our experiment had a lottery ticket, $49 \%$ did not win a prize at all, 39\% won less than 10 euro, $11 \%$ won a prize between 10 and 100 euro, and $1 \%$ won a prize larger than 100 euro. On average, we do not find evidence for procedural utility after the draw, originating from winning a small prize. Lottery winners did not experience a significantly larger change in happiness between $T_{1}$ and $T_{3}$ compared to non-players. Nevertheless, as shown in panel A of Table 4 there is a significant difference between those that had a lottery ticket and won a prize and those that had a lottery ticket and did not win a prize.

Panel B of Table 4 shows the parameter estimates if we also make a distinction between the ways through which the individual got a lottery ticket, i.e. purchased, free or both. Now we find that there is only a positive and significant effect for those with a small prize and a free ticket, while at the same time the winners with a free ticket are significantly happier than winners with both free and purchased tickets. These results are independent of whether or not we include control variables and the change in life satisfaction.

We conclude from these estimations that only a combination of not having purchased a lottery ticket and receiving one for free and winning a prize leads to an increase in happiness and that the effect of a small prize is very limited. The latter conclusion is supported by a test in which participants $(n=401)$ who did not see the results of the lottery draw had the opportunity to look up the results via a link in the survey to check whether they had won or not won a prize in the lottery. ${ }^{19}$ This opportunity was provided after the question asking how the participants felt today. At the end of the survey, participants were asked how happy they were feeling at this moment on a scale from 0 to 10 . Respondents who viewed the link and won a prize were not significantly happier than respondents who viewed the link and did not win a prize $(p=0.93)$. This result was found regardless of whether one had a purchased ticket $(p=0.13)$, a free and purchased ticket $(p=0.49)$, or a free ticket $(p=0.87)$.

As a robustness check, we also examined differences in specific emotions after the draw. Again participants were asked which emotions they experienced when they thought back about participating in the draw of the State Lottery on May 10th. Although winners reported to be happier and less disappointed, winners and nonwinners did only marginally differ regarding the other experienced emotions regarding the draw (see Fig. 2). In a further analysis, we only found evidence for procedural utility for winners that were already positive about the lottery before the draw. ${ }^{20}$ This fuels the idea that the procedural non-monetary utility derived from winning a (small) prize is rather limited.

\footnotetext{
${ }^{19}$ People were asked whether they already saw the results. If not, they were offered the opportunity to view the results via a link.

20 This analysis is available upon request.
} 


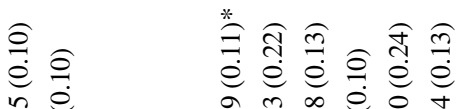

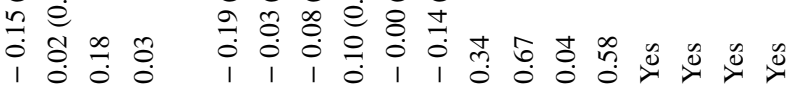

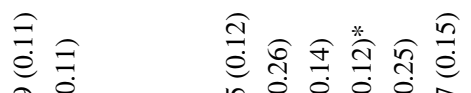

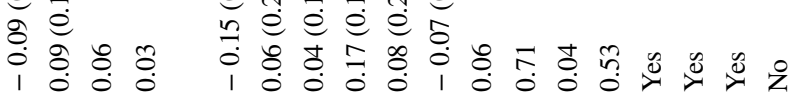

Iิ

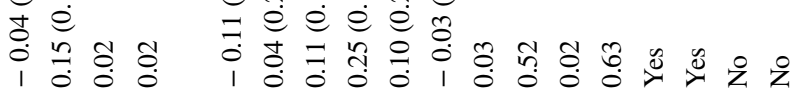

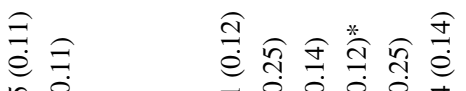

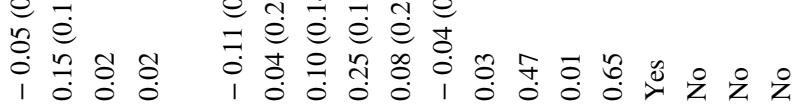

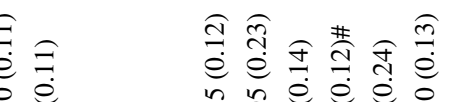

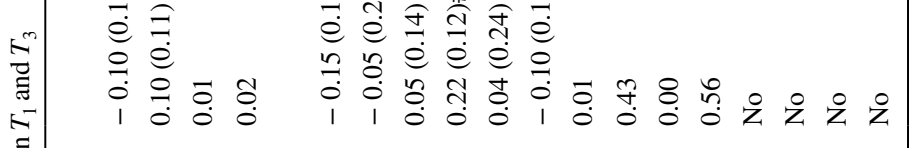

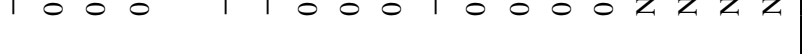

舫

趈

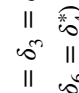

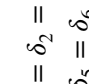

क्ष

.

范

‥ ․․ㄹ

ज्ञ

总

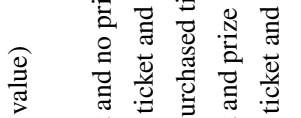

क्ष

$\frac{\pi}{2}$

क्षे :

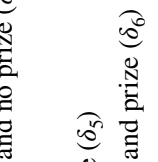

के है

की चี

के

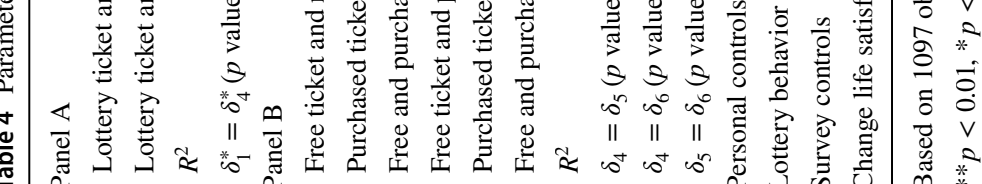

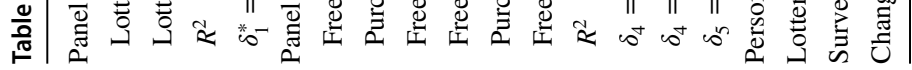

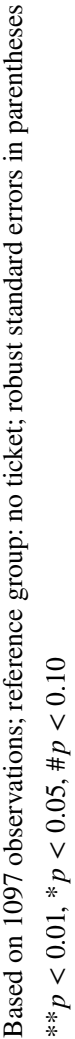




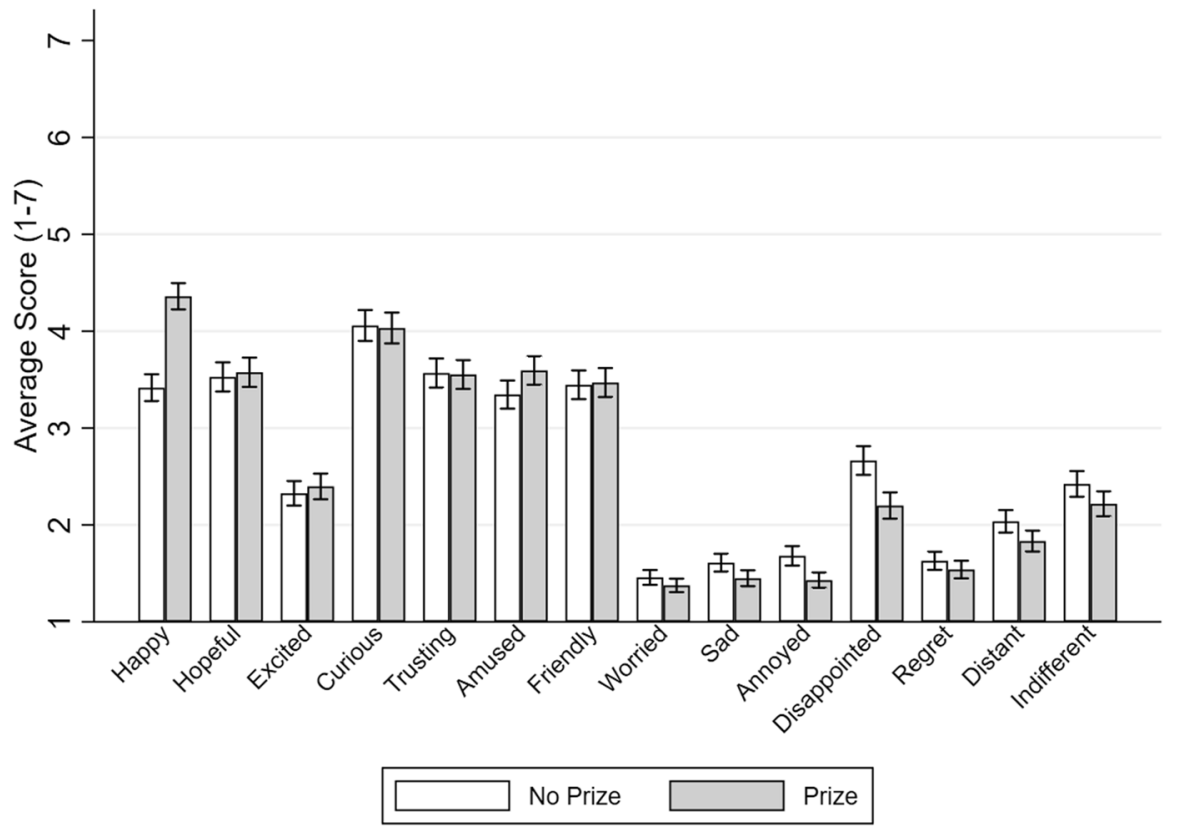

Fig. 2 Emotions experienced after the draw by winners and non-winners Note: Only for respondents who possessed a lottery ticket for the lottery draw of May 10; average answers to questions on emotions on a scale from 1 (not at all) to 7 (completely)

\section{Discussion and conclusions}

From a financial point of view buying a lottery ticket is not a rational investment as the average ex-post value of a ticket is just over half the price of that ticket. Nevertheless, many people participate in lotteries. There are two popular explanations in the economics literature for this: (1) low cost opportunities to improve one's financial position if there are few opportunities to do this otherwise and (2) prospect theory according to which people overweight the small probability of winning a lottery. The first explanation suggests that participation would be predominantly among lower social classes which is not the case since lottery play takes place across the whole income distribution. The second explanation is at odds with the finding that most lottery participants have quite accurate expectations about the probability to win a prize. Although there is some empirical support for both the Friedman-Savage theory and prospect theory, these theories only partly explain people's propensity to gamble.

We studied lottery participation using a field experiment in which some participants of a regular household survey received a state lottery ticket for free, while other participants had no ticket or only a purchased ticket, or both a free and a purchased ticket. This allows us to investigate to what extent participating in a lottery increases momentary happiness. If so, this supports a third explanation of lottery 
participation, i.e. people deriving non-monetary utility from participating in a lottery play. This could be because of the hope of winning a large prize, the fun and excitement of the game, or because of social bonding activities when playing the lottery together with family or friends.

In our field experiment, momentary happiness is measured at three moments in time, i.e. before free lottery tickets are issued, after providing some individuals with a free lottery ticket but before the draw, and after the draw. We study the change in momentary happiness between the first two moments to investigate whether playing in the lottery increases momentary happiness, regardless of whether the ticket was bought or free. We also study the change in momentary happiness between the first and third moment to investigate to what extent winning a small lottery prize matters.

Our main finding is that participants in a lottery derive procedural utility from playing the game. This is irrespective of whether the lottery ticket was bought or received for free due to the experiment. On a scale from 1 to 10 , participating in a lottery increases momentary happiness with $0.25-0.40$ (approximately 1/5-1/3 standard deviation increase). These results may be driven by the hope and expectations about financial gains, the thrill of a potential win, and social bonding when playing as a group. However, the procedural utility that players derive from winning a small prize is limited. In sum, we conclude that lottery participation seems to be at least partly driven by the joy of lottery play, i.e. lottery participants may be hoping for financial gains but gamble for fun. More generally, our research shows the importance of taking in procedural utility in modeling decisions of consumers since consumers do not only care about outcomes, but also about the process. Accordingly and in line with previous work, seemingly irrational decisions such as lottery play could be considered rational from the perspective of procedural utility (see also Benz 2005).

It is important to note that our results are related to the probability of winning which is about $50 \%$ in the State Lottery. For lotteries with a smaller winning probability the magnitude of the happiness effects are smaller. It is also important to note that our article has focused on the short-term positive impact on lottery play through procedural utility and does not pay attention to the potential negative long-term effects of lottery play, especially in the case of problem and pathological gambling (Lorenz 1990). In this regard, lottery gambling has been associated with psychological, social, and economic problems. Hence, procedural utility may induce suboptimal decision-making in the long-run. At the same time, the number of problem lottery gamblers among the population is relatively small (Hendriks et al. 1997) and the overall long-term effects of lottery play on overall well-being or experienced quality of life seem to be limited (Burger et al. 2016). However, more research on the consequences of lottery play are needed to examine the long-term effects of lottery play.

\section{Compliance with ethical standards}

Conflict of interest The authors declare that they have no conflict of interest. The authors have received funding from the State Lottery for data collection. Apart from this, no funding was used to conduct the 
present study, and the financiers of the data collection had no role in the study design, data collection and analysis, decision to publish, or preparation of the manuscript.

Open Access This article is licensed under a Creative Commons Attribution 4.0 International License, which permits use, sharing, adaptation, distribution and reproduction in any medium or format, as long as you give appropriate credit to the original author(s) and the source, provide a link to the Creative Commons licence, and indicate if changes were made. The images or other third party material in this article are included in the article's Creative Commons licence, unless indicated otherwise in a credit line to the material. If material is not included in the article's Creative Commons licence and your intended use is not permitted by statutory regulation or exceeds the permitted use, you will need to obtain permission directly from the copyright holder. To view a copy of this licence, visit http://creativecommons.org/licen ses/by/4.0/.

\section{Appendix A: Overview of control variables}

- Personal characteristics

- Female: Dummy variable indicating whether the respondent is female

- Age: Age in years

- Employed: Dummy variable indicating whether the respondent is working

- Unemployed: Dummy variable indicating whether the respondent is unemployed

- High household income: dummy variable indicating whether the net monthly household income is over $€ 2600$

- High education level: Dummy variable indicating whether the respondent finished at least a study program at ISCED 5-6 level

- High socio-economic status: Self-assessed status regarding salary, job and social status.

- Partner: Dummy variable indicating whether the respondent has a partner

- Children: Dummy variable indicating whether the respondent has children

- Urban environment and region: Dummy variables indicating level of urbanity of residence is at least high or very high; Dummy variable whether the respondent lives in the North, East, or South of the Netherlands (West is reference group)

- Personality characteristics (including gambling behavior)

- Materialism: Score on Richins's Material Values Scale (Richins 2004)

- Optimism: Score on the Life Orientation Test—Revised (Scheier et al. 1994)

- Internal locus of control: Score on Short version of the Levenson IPC scale (Sapp and Harrod 1993)

- Frequency of lottery participation: Dummy variable indicating that a respondent has at least participated in the State lottery a few times in the last year

- Won in past year: Dummy variable indicating the respondent has had a win in the State lottery in the past year 
Table 5 Descriptive statistics

\begin{tabular}{|c|c|c|c|c|c|c|}
\hline \multirow[t]{2}{*}{ Variables } & \multicolumn{3}{|c|}{ Tables $1-3(N=1142)$} & \multicolumn{3}{|c|}{ Table $4(\mathrm{~N}=1096)$} \\
\hline & Mean & Min & $\operatorname{Max}$ & Mean & Min & $\operatorname{Max}$ \\
\hline Change in happiness $\left(T_{1}-T_{2}\right)$ & -0.10 & -7 & 6 & & & \\
\hline Change in happiness $\left(T_{1}-T_{3}\right)$ & & & & -0.22 & -7 & 6 \\
\hline Lottery ticket & 0.89 & 0 & 1 & & & \\
\hline Free ticket & 0.59 & 0 & 1 & & & \\
\hline Purchased ticket & 0.04 & 0 & 1 & & & \\
\hline Free and purchased ticket & 0.26 & 0 & 1 & & & \\
\hline Thought about lottery & 0.76 & 0 & 1 & & & \\
\hline Thought sometimes about lottery & 0.61 & 0 & 1 & & & \\
\hline Thought frequently about lottery & 0.15 & 0 & 1 & & & \\
\hline Lottery ticket and no prize & & & & 0.44 & 0 & 1 \\
\hline Lottery ticket and prize & & & & 0.45 & 0 & 1 \\
\hline Free ticket and no prize & & & & 0.32 & 0 & 1 \\
\hline Purchased ticket and no prize & & & & 0.01 & 0 & 1 \\
\hline Free and purchased ticket and no prize & & & & 0.11 & 0 & 1 \\
\hline Free ticket and prize & & & & 0.27 & 0 & 1 \\
\hline Purchased ticket and prize & & & & 0.02 & 0 & 1 \\
\hline Free and purchased ticket and prize & & & & 0.16 & 0 & 1 \\
\hline Female & 0.47 & 0 & 1 & 0.47 & 0 & 1 \\
\hline Age & 56.78 & 18 & 92 & 56.61 & 18 & 92 \\
\hline Employed & 0.46 & 0 & 1 & 0.46 & 0 & 1 \\
\hline Unemployed & 0.08 & 0 & 1 & 0.08 & 0 & 1 \\
\hline High household income & 0.46 & 0 & 1 & 0.46 & 0 & 1 \\
\hline High education level & 0.39 & 0 & 1 & 0.38 & 0 & 1 \\
\hline High socio-economic status & 0.21 & 0 & 1 & 0.21 & 0 & 1 \\
\hline Partner & 0.69 & 0 & 1 & 0.68 & 0 & 1 \\
\hline Children & 0.26 & 0 & 1 & 0.26 & 0 & 1 \\
\hline Urban environment & 0.40 & 0 & 1 & 0.40 & 0 & 1 \\
\hline Northern Netherlands & 0.13 & 0 & 1 & 0.13 & 0 & 1 \\
\hline Eastern Netherlands & 0.19 & 0 & 1 & 0.19 & 0 & 1 \\
\hline Southern Netherlands & 0.25 & 0 & 1 & 0.25 & 0 & 1 \\
\hline Materialism & 26.66 & 9 & 56 & 26.68 & 9 & 56 \\
\hline Optimism & 29.25 & 9 & 42 & 29.27 & 9 & 42 \\
\hline Internal locus of control & 45.59 & 25 & 63 & 45.61 & 25 & 62 \\
\hline Frequent lottery participation & 0.64 & 0 & 1 & 0.64 & 0 & 1 \\
\hline Won in past year & 0.02 & 0 & 1 & 0.02 & 0 & 1 \\
\hline Thinks chance of winning is high & 0.17 & 0 & 1 & 0.17 & 0 & 1 \\
\hline$\Delta$ duration questionnaires $T_{1}-T_{2}$ & -29.29 & -5590.83 & 1486.93 & & & \\
\hline$\Delta$ enjoyability questionnaires $T_{1}-T_{2}$ & 0.07 & -4 & 4 & & & \\
\hline$\Delta$ difficulty questionnaires $T_{1}-T_{2}$ & -0.77 & -4 & 4 & & & \\
\hline$\Delta$ life satisfaction $T_{1}-T_{2}$ & -0.13 & -9 & 6 & & & \\
\hline$\Delta$ duration questionnaires $T_{1}-T_{3}$ & & & & -18.76 & -5589.87 & 2143.21 \\
\hline
\end{tabular}


Table 5 (continued)

\begin{tabular}{|c|c|c|c|c|c|c|}
\hline \multirow[t]{2}{*}{ Variables } & \multicolumn{3}{|c|}{ Tables $1-3(\mathrm{~N}=1142)$} & \multicolumn{3}{|c|}{ Table $4(\mathrm{~N}=1096)$} \\
\hline & Mean & Min & $\operatorname{Max}$ & Mean & Min & $\operatorname{Max}$ \\
\hline$\Delta$ enjoyability questionnaires $T_{1}-T_{3}$ & & & & 0.08 & -4 & 4 \\
\hline$\Delta$ difficulty questionnaires $T_{1}-T_{3}$ & & & & -0.81 & -4 & 4 \\
\hline$\Delta$ life satisfaction $T_{1}-T_{3}$ & & & & -0.16 & -9 & 6 \\
\hline
\end{tabular}

- Thinks chance of winning is high: Dummy variable indicating that the respondent assessed the chances of ever winning a large price is high (larger than a score of 3 on a seven-point scale)

- Perceived survey characteristics

- Change in duration questionnaire: Difference in duration of questionnaire in minutes for the different time points.

- Change in enjoyability questionnaire: Difference in enjoyability for the different time points. Based on the question: Did you enjoy filling out this questionnaire? $(1=$ Not at all; $5=$ Very much $)$.

- Change in difficulty questionnaire: Difference in duration of questionnaire for the different time points. Based on the question: Did you find it difficult answering the questions in this questionnaire? $(1=$ Not at all; $5=$ Very much).

- Change in life satisfaction: Change in life satisfaction score between two surveys. Based on the question: All things considered, how satisfied are you with your life-as-a-whole? $(1=$ very dissatisfied; $10=$ very satisfied $)$ (Table 5).

\section{References}

Ariyabuddhiphongs, V. (2011). Lottery gambling: A review. Journal of Gambling Studies, 27, 15-33.

Ariyabuddhiphongs, V., \& Chanchalermporn, N. (2007). A test of social cognitive theory reciprocal and sequential effects: Hope, superstitious belief and environmental factors among lottery gamblers in Thailand. Journal of Gambling Studies, 23, 201-214.

Beckert, J., \& Lutter, M. (2013). Why the poor play the lottery: Sociological approaches to explaining class-based lottery play. Sociology, 47, 1152-1170.

Benz, M. (2005). The relevance of procedural utility for economics. In Working paper institute for empirical research in economics, University of Zurich, no. 256.

Brunk, G. G. (1981). A test of the Friedman-Savage gambling model. The Quarterly Journal of Economics, 96(2), 341-348.

Bruyneel, S., Dewitte, S., Franses, P. H., \& Dekimpe, M. G. (2005). Why consumers buy lottery tickets when the sun goes down on them. The depleting nature of weather-induced bad moods. Advances in Consumer Research, 33, 46-47.

Burger, M., Hendriks, M., Pleeging, E., \& van der Zwan, P. W. (2016). The silver linings of lottery play: Motivation and subjective well-being of British lottery participants. Applied Economics Letters, 23, 1312-1316. 
Chadi, A. (2013). The role of interviewer encounters in panel responses on life satisfaction. Economics Letters, 121, 550-554.

Clarke, D. (2005). Motivational differences between slot machine and lottery players. Psychological Reports, 96, 843-848.

Clotfelter, C. T., \& Cook, P. J. (1990). On the economics of state lotteries. The Journal of Economic Perspectives, 4, 105-119.

Conlisk, J. (1993). The utility of gambling. Journal of Risk and Uncertainty, 6, 255-275.

Eadington, W. R. (1973). The economics of gambling behavior: A qualitative study of Nevada's gambling industry. Bureau of Business and Economic Research: University of Nevada.

Felsher, J. R., Derevensky, J. L., \& Gupta, R. (2004). Lottery playing amongst youth: Implications for prevention and social policy. Journal of Gambling Studies, 20(2), 127-153.

Forrest, D., Gulley, O. D., \& Simmons, R. (2000). Testing for rational expectations in the UK national lottery. Applied Economics, 32, 315-326.

Frey, B. S., Benz, M., \& Stutzer, A. (2004). Introducing procedural utility: Not only what, but also how. Journal of Institutional and Theoretical Economics, 160(3), 377-401.

Friedman, M., \& Savage, L. J. (1948). The utility analysis of choices involving risk. Journal of Political Economy, 56(4), 279-304.

Frey, B. S., \& Stutzer, A. (2002). What can economists learn from happiness research? Journal of Economic Literature, 40, 402-435.

Garrett, T. A., \& Sobel, R. S. (1999). Gamblers favor skewness, not risk: Further evidence from United States' lottery games. Economics Letters, 63, 85-90.

Garvía, R. (2007). Syndication, institutionalization, and lottery play. American Journal of Sociology, 113(3), 603-652.

Guillén, M. F., Garvía, R., \& Santana, A. (2011). Embedded play: Economic and social motivations for sharing lottery tickets. European Sociological Review, 28, 344-354.

Hartley, R., \& Farrell, L. (2002). Can expected utility theory explain gambling? American Economic Review, 92, 613-624.

Hendriks, V. M., Meerkerk, G. J., Van Oers, H. A., \& Garretsen, H. F. (1997). The Dutch instant lottery: Prevalence and correlates of atrisk playing. Addiction, 92(3), 335-346.

Hirshleifer, J. (1966). Investment decision under uncertainty: Applications of the state-preference approach. The Quarterly Journal of Economics, 80, 252-277.

Kahneman, D., \& Tversky, A. (1979). Prospect theory: An analysis of decisions under risk. Econometrica, 47(2), 263-292.

Kearney, M. S. (2005). State lotteries and consumer behavior. Journal of Public Economics, 89, 2269-2299.

Kocher, M. G., Krawczyk, M., \& van Winden, F. (2014). Let me dream on! Anticipatory emotions and preference for timing in lotteries. Journal of Economic Behavior and Organization, 98, 29-40.

Le Menestrel, M. (2001). A process approach to the utility for gambling. Theory and Decision, 50, 249-262.

Loewenstein, G. (1987). Anticipation and the valuation of delayed consumption. The Economic Journal, 97(387), 666-684.

Lorenz, V. C. (1990). State lotteries and compulsive gambling. Journal of Gambling Studies, 6(4), 383-396.

Miyazaki, A. D., Langenderfer, J., \& Sprott, D. E. (1999). Government-sponsored lotteries: Exploring purchase and nonpurchase. Psychology and Marketing, 16, 1-20.

Nederlandse Staatsloterij, Annual Report 2015 (in Dutch) (Rijswijk, 2016).

Nyman, J. A., Welte, J. W., \& Dowd, B. E. (2008). Something for nothing: A model of gambling behavior. The Journal of Socio-Economics, 37, 2492-2504.

Perez, L., \& Humphreys, B. (2013). The 'who and why' of lottery: Empirical highlights from the seminal economic literature. Journal of Economic Surveys, 27, 915-940.

Pryor, F. L. (1976). The Friedman-Savage utility function in cross-cultural perspective. Journal of Political Economy, 84(4), 821-834.

Richins, M. L. (2004). The material values scale: Measurement properties and development of a short form. Journal of Consumer Research, 31, 209-219.

Sapp, S. G., \& Harrod, W. J. (1993). Reliability and validity of a brief version of Levenson's locus of control scale. Psychological Reports, 72, 539-550. 
Scheier, M. F., Carver, C. S., \& Bridges, M. W. (1994). Distinguishing optimism from neuroticism (and trait anxiety, self-mastery, and self-esteem): A reevaluation of the Life Orientation Test. Journal of Personality and Social Psychology, 67, 1063-1078.

Scott, F., \& Gulley, O. (1995). Testing for efficiency in lotto markets. Economic Inquiry, 33, 175-188.

Sheremeta, R. M. (2010). Experimental comparison of multi-stage and one-stage contests. Games and Economic Behavior, 68, 731-747.

Teppa, F., \& Vis, C. (2012). The CentERpanel and the DNB household survey: Methodological aspects. Netherlands Central Bank, DNB Occasional Studies, 10, 4.

The European Lotteries. (2015). Report on the Lottery Sector in Europe 2015.

Van Landeghem, B. (2014). A test based on panel refreshments for panel conditioning in stated utility measures. Economics Letters, 124, 236-238.

Veenhoven, R. (2000). The four qualities of life. Ordering concepts and measures of the good life. Journal of Happiness Studies, 1, 1-39.

Veenhoven, R. (2018). Happiness in The Netherlands, World Database of Happiness: Erasmus University Rotterdam. http://worlddatabaseofhappiness.eur.nl.

Walker, I. (1998). The economic analysis of lotteries. Economic Policy, 13, 358-401.

Publisher's Note Springer Nature remains neutral with regard to jurisdictional claims in published maps and institutional affiliations. 